\title{
Legal Assistance and Police Interrogation
}

\author{
(Problematic Aspects of) Dutch Criminal Procedure in Relation to European Union and the \\ Council of Europe
}

Paul Mevis \& Joost Verbaan*

\begin{abstract}
This paper discusses the rise of a fundamental issue in Dutch criminal proceedings. The presence of a lawyer prior to and during police interrogations has for a long time been a matter open for debate in the Netherlands. Allowing legal assistance during and prior to police interrogations has been researched on several occasions in the previous century and the beginning of this century. In the Netherlands, one of the most important reasons for not admitting legal assistance was and is founded in the confident reliance on the professionalism and integrity of police officers and justice officials in dealing with the interests of suspects. However, after the Salduz case (ECHR 27 November 2008, Appl. No. 36391 / 02, Salduz v. Turkey), the Dutch government was compelled to draft legal provisions in order to facilitate legal assistance during and prior to police interrogations. The initial
\end{abstract}

drafts still contained a hesitant approach on admitting the lawyer to the actual interrogation. The EU-Directive of November 2013 (Pb EU 2013, L249) set out further reaching standards compelling the Dutch government to create new drafts. In a ruling of April 2014, the Dutch Supreme Court (ECLI:NL:2014:770) argued that the judgements of the ECtHR were too casuistic to derive an absolute right to have a lawyer present during police interrogation. However, they urged the legislator to draft legislation on this matter and warned that its judgement in this could be altered in future caused by legal developments. The Dutch legislator already proposed new draft legislation in February. In this paper it is examined whether the provisions of the new drafts meet the standards as set out in the EU-Directive as well as by the ECtHR.

Keywords: Legal assistance, police interrogation, Dutch Criminal Proceedings, EU Directive

\section{Introduction and Context: The Rise of a Fundamental Issue in Dutch Criminal Procedure Law and the Reasons behind This}

Developments in the field of legal assistance prior to, during, and after interrogation by the police can be perceived as the most turbulent and radical change in Dutch Criminal Proceedings of the past years. There are several reasons for this. First of all, Dutch Criminal Proceedings have no tradition in providing the suspect or the accused with protection in the form of legal assistance based on a thoroughly regulated system prior to, during, and after police interrogation. Instead, there is and has been a confident reliance on the professionalism and integrity of police officers and justice officials in dealing with the interests of the suspect and the accused. Although the notification of a (standby) lawyer has been required for some time when a suspect or an accused person is detained in police custody, this has never generally been considered necessary for safeguarding the rights of the suspect or the accused person prior to, during, or after the interrogation. There was 
therefore no rule stating that the arrival of a lawyer had to be awaited before interrogation could commence or that the suspect or accused person should have contact with his lawyer. In general, the assumption was that the professionalism and integrity of interrogating officers was satisfactory as far as the just and complete reflection of the statements made by the suspect or accused person in official reports was concerned ${ }^{1}$ and as far as illtreatment or mistreatment of the suspect or accused was concerned. Legal assistance during interrogation was not considered necessary for these guarantees. For the same reasons, the consultation of a lawyer prior to the first interrogation to ensure the suspect or the accused was informed of his rights during the interrogation was also not considered necessary. In other words, it is the interrogating officer (himself) who is obliged to mirandize the suspect or the accused regarding the right to remain silent during interrogation. Against this background, legal developments to strengthen guarantees of legal assistance prior to or during interrogation were, and perhaps are still, all too soon interpreted as an unjust sign of distrust towards police criminal investigators. This also explains why the first suggestions by the Council of Europe, that the Dutch rules offer too few guarantees in the field of legal assistance to the suspect or the accused prior to and during interrogations, were not taken very seriously by the police nor by the government. As early as 1991 further to the identification of (alleged) mistreatment during police interrogations, for example, in France, the first suggestions that these guarantees are weak were made by the CPT. In the Netherlands, however, the CPT's findings were soon labelled as 'soft law', which is not compulsory as far as amending Dutch law is concerned, even more so when this soft law regards the 'freedom' of police to interrogate suspects or accused persons upon arrest without too much concern about safeguarding their rights to legal assistance: a 'freedom' embedded in Dutch legal culture. The danger of mistreatment during police interrogation was, presumably with good reason, not considered as the biggest threat to the suspect or the accused. This explains why the Dutch government initially rejected all calls to recognise the right to the presence of a lawyer during police interrogation that were formulated by the CPT in,inter alia, its reports on visits to the Netherlands in 1992 and 1997. ${ }^{2}$ Nevertheless, the CPT had touched upon an issue that every now and then was the subject of debate about criminal procedure law in the Netherlands.

This restrained attitude of the Netherlands towards the right to legal assistance prior to and during police interrogation, as developed by the Council of Europe, only started to change when this right became grounded in the rulings of the European Court of Human Rights

1. As stated in Art. 152 CPC, police officers have to relate in police reports on criminal offences they detect or on acts they performed in order to detect the criminal offence.

2. C.J.C.F. Fijnaut, Het vooronderzoek in strafzaken. Tweede interimrapport onderzoeksproject strafvordering (2001), at 703.
(ECtHR) ${ }^{3}$ making it more influential and thus inevitable for Dutch practice and regulations in the field of criminal procedure law. After a number of initial cases pointing towards this right such as Can v. Austria, S. v. Smitzerland, Imbrioscia v. Smitzerland, Murray v. the United Kingdom, Selmouni v. France, and Condron a.o. v. the United Kingdom, on 27 November 2008, the Grand Chamber of the European Court pronounced its ruling in the case of Salduz v. Turkey. ${ }^{4}$ Two aspects of this ruling are of particular interest. ${ }^{5}$ The guarantee of legal assistance prior to and during police interrogation is placed within the scope of 'the prevention of miscarriages of justice' and 'the fulfillment of the aims of Article 6 , notably equality of arms between the investigating or prosecuting authorities and the accused', as, under reference to the earlier reports and approach of the CPT, a 'safeguard against ill-treatment'. Secondly, the Grand Chamber explicitly commented on the legal consequences of violating these rights: 'The rights of the defence will in principle be irretrievably prejudiced when incriminating statements made during police interrogation without access to a lawyer are used for a conviction'. In other words, any statement made by a suspect or accused person during police interrogation, and during which his rights relating to this specific point were violated, are inadmissible as evidence. An international court ruling on the use of evidence in criminal cases, based on an international treaty on guarantees in criminal proceedings, is regarded rather extensively. Only in obvious cases of torture (UN Convention against Torture) as well as violations of Article 3 of the ECHR can the first steps in this be found. ${ }^{6}$ The immediate effect of ECtHR rulings is relevant to the Netherlands. The Salduz ruling is interesting because of the above two aspects regardless of whether or not this ruling can be interpreted as establishing a right for an adult suspect or accused to the presence of a lawyer during police interrogation. Nonetheless, the Dutch government was faced with the challenge of complying with the ECtHR's approach. However, before discussing the Dutch response, some other developments need to be outlined. As stated, neither the need to protect the suspect or accused person against ill-treatment nor the need to further detail the 'equality of arms' deriving from Article 6 of the ECHR was enough to bring about change in existing Dutch legislation or practice. Such change was even not deemed necessary after the emergence of individual cases in which interrogation methods violated or came close to violating the suspect's or accused's right

3. On the basis of the Dutch Constitution, the binding treaty provisions of international treaties and decisions of international organisations such as the ECtHR have direct effect within the Dutch criminal justice system; in addition, they take precedence over any possible conflicting provisions of national law.

4. ECHR 27 November 2008, Appl. No. 36391/02, Salduz v. Turkey, ECLI:NL:HR:BH0402.

5. ECHR 27 November 2008, Appl. No. 36391/02, Salduz v. Turkey, $\S \S 50-55$.

6. See the clause concerned in ECHR 30 June 2008, Appl. No. 22978/05, Gäfgen v. Germany, Grand Chamber. 
to remain silent. ${ }^{7}$ Initially the same applied with regard to preventing miscarriages of justice. However, this changed when the Netherlands was confronted with some cases involving miscarriages of justice that attracted significant media attention. Specifically, the mistakes made in the preliminary investigation in the case known as the 'Schiedammer parkmoord' led to the initiation in July 2008 of a biennial experiment 'raadsman bij verhoor' ${ }^{8}$ following the adoption by parliament of Dittrich's 9 resolution and the programme 'Enforcing Investigation and Prosecution' designed to optimise truth finding in criminal cases. ${ }^{10}$ The Salduz approach of the ECtHR clearly resounds in the choice for and continuing of this apparently truth-finding self-explanatory experiment. The contents and significance of this ruling have, albeit hesitantly and contrary to the Dutch tradition of regulations and police interrogations, increased and eased acceptance of the modality of a lawyer being present during police interrogation.

The ruling in the Salduz case indeed took on such importance for the regulation and practice of legal representation surrounding the police interrogation that it became necessary to amend regulations and practice. This was done at three levels. The criminal division of the Dutch Supreme Court, 'de Hoge Raad der Nederlanden', made a guiding decision on the consequences of the Salduz case for the Netherlands in June 2009. ${ }^{11}$ In this case, the Supreme Court decided that the ECtHR rulings implied that a suspect or accused detained by the police has the right to legal assistance, i.e., he should be offered the opportunity to communicate with a lawyer prior to his interrogation by the police. However, it was also decided that these rulings did not imply the right to the presence of a lawyer during the interrogation itself. ${ }^{12}$ The first part of the decision of the Supreme Court applies to adults under criminal law as well as minors under criminal law (in the Netherlands: younger than 18 years). However, the assumption was made that according to the European jurisprudence, minors under criminal law also have the right to be assisted by a lawyer or other confidant during police interrogation. ${ }^{13}$

The decision not to allow a lawyer to be present during interrogation was confirmed by the Supreme Court even a few months after the Directive (to be discussed later). This Directive which regards the right of access to a lawyer during criminal proceedings and the right to communicate upon arrest was adopted by the European

7. In a general sense see Fijnaut, above n. 2, at 741 and T. Blom, 'Vormen verzuimd tijdens het politieverhoor', Inauguration, University of Amsterdam, Vossius UvA, Amsterdam (2010).

8. L. Stevens and W.J. Verhoeven, Raadsman bij politieverhoor, The Hague (2010).

9. Motion of 25 October 2006, Parliamentary Papers II, 2006-2007, 30800 VI, No. 14

10. Programma Versterking Opsporing en Vervolging, November 2005.

11. ECLI:NL:HR:2009:BH3079; see also detailed Opinion of the AdvocateGeneral at the Supreme Court, ECLI:NL:PHR:2009:BH3079.

12. ECLI:NL:HR:2009:BH3079, para. 2.5

13. ECLI:NL:HR:2009:BH3079, para. 2.6.
Union. ${ }^{14}$ This verdict underlines the restrained Dutch approach of the presence of a lawyer during police interrogations.

In this particular case, the Dutch Supreme Court found motives to recognise the right to have a lawyer present during police interrogation neither in the Navone and others v. Monaco case ${ }^{15}$ nor in the above-mentioned Directive. These findings were, in short, justified by two important arguments. The first argument stated by the Supreme Court was the argument that despite the fact that the Directive was adopted by the European Union, implementation of this Directive is set to take effect on 27 November 2016 and therefore explicitly not entered into force, thus accepting that certain Member States currently do not meet the terms set out in the Directive. ${ }^{16}$ The other argument was that the Supreme Court notices that, at the time of the verdict, no such regulations existed, due to the lack of a legal regulation regarding this part of the mentioned Directive. The Dutch Supreme Court, bearing the political and policy considerations as well as the organisational and financial aspects in mind, added that creating a general regulation regarding legal assistance during police interrogation would exceed its judicial function. ${ }^{17}$

In Dutch criminal law practice, it is the police who is responsible for executing the interrogation of the suspect or accused under the authority of the public prosecutor in charge of the investigation. The heads of the Public Prosecution and/or the Ministry of Security and Justice supervise this in the form of guidelines and directives that should be followed as a rule. Politically the Minister of Security and Justice is held responsible for the substance of these guidelines and directives. Within this context, the public prosecutors' 'Guidelines for legal assistance and police interrogation' came into effect on 1 April 2010. ${ }^{18}$ These guidelines determine how the issue of legal assistance prior to the first police interrogation should be dealt with. ${ }^{19}$

The above developments relating to legal assistance also called for legislative amendments of the Dutch Penal Code. Decisions that are too political or that influence the very core of the Dutch system of criminal proceedings have to be made by parliamentary legislation. The principle of legality that applies to criminal procedure law also requires this. In the Netherlands it is not uncommon for the Ministry of Security and Justice, as the initiating party when it comes to legislation, to publish a proposed legislative amendment, a so-called 'draft bill', and present this for legally qualified debate and commentary whilst requesting several official institutes, such as the public prosecutor or the judiciaries for

14. Directive 2013/48/EU, 22 October 2013, Pb EU L249.

15. Navone and others v. Monaco, 24 October 2013, Nos. 62880/11, 62892/11 and 62899/11.

16. ECLI:NL:HR:2014:770, paras. 2.5.2.

17. ECLI:NL:HR:2014:770, paras. 2.5.3

18. Instructions regarding legal assistance in relation to police interrogation (2010A007), Government Gazette, 2010, No. 4003

19. For a detailed report of the evaluation of the guidelines in practice, see Stevens and Verhoeven, above n. 8. 
advice. A final bill is then drafted based on the comments and advice to be presented to parliament. On 22 March 2011, the Dutch legislator presented a first draft bill on legal assistance and police interrogation. ${ }^{20}$ The absence of a tradition with the presence of a lawyer was reflected by the first proposal. The rights to communicate with a lawyer and to have him present during interrogation by police were limited by many thresholds. It was thus not surprising that the first draft bill was regarded redundant, when the Directive, $\mathrm{Pb} \mathrm{EU}$ 2013, L 294, founded on - amongst others - the verdict in the Salduz case, ${ }^{21}$ was adopted by the EU. ${ }^{22}$

As a result of the content of the Directive, the initial presented draft bill has been altered and divided into two draft bills. ${ }^{23}$ One draft bill provides only the necessary components to implement the wordings and rights of the Directive, Pb EU 2013, L 294, which next to the right to access to a lawyer entails the right to appoint a lawyer in a Member State as a part of European Arrest Warrant proceedings, as well as the possibility for a suspect to inform a third party of the deprivation of liberty and to communicate with a third party and consular authorities. The other draft bill complements the regulations of the Dutch Criminal Procedure regarding the first phase of the investigative procedures in a criminal case. This supplement contributes to integrating the access to a lawyer, as created by the Directive, in the Criminal Procedures as a part of the investigative procedures.

The initially proposed, later-changed draft bill ${ }^{24}$ already contained a few aspects of particular interest. It proposed adding new rules to the Criminal Code which were supposed to make it possible for the suspect or accused person to have legal assistance at an earlier stage than is possible under current, national-Dutch legal regulations. This proposal was in line with current practice that already deviates from existing legislation in the Criminal Procedure and with the guidelines referred to above. These new rules give the suspect or accused detained by the police for interrogation the right to consult his or her lawyer prior to interrogation. There were no exceptions to this right although it could be waived by the suspect or accused. Next to that, this first draft bill provided the right to have a lawyer present during interrogation. However, this provision was limited to cases in which the suspect or accused was suspected of having committed an offence punishable by a minimum term of imprisonment of six years which in effect meant a limitation of legal assistance during interrogation to serious offences. The drafters of the first draft bill based this not insignificant restriction in the right to legal

20. See: <www.rijksoverheid.nl/documenten-en-publicaties/regelingen/ 2011/04/18/wetsvoorst-rechtsbijstand-en-politieverhoor.html>.

21. Directive 2013/48/EU, 22 October 2013, Pb EU L249, preambule para. 21.

22. Published in the Official Journal of the EU on 6 November 2013.

23. Newsfeed of the Dutch Government, 13 February 2014; see: <www. rijksoverheid.nl/nieuws/2014/02/13recht-op-bijstand-van-raadsmantijdens-politieverhoor.html>.

24. Draft bill on legal assistance and police interrogation, 22 March 2011. assistance during police interrogation on the ruling of the ECtHR in the Salduz case. The fact that the Court in this particular case pointed out that the right to legal assistance deriving from Article 6 of the ECHR is not unlimited was considered a motive for this limitation:

51. The Court further reiterates that although not absolute, the right of everyone charged with a criminal offence to be effectively defended by a lawyer, assigned officially if need be, is one of the fundamental features of a fair trial (see Poitrimol v. France, $\S 34,{ }^{25}$ and Demebukov v. Bulgaria, $\S 50^{26}$ ). Nevertheless, Article $6 \S 3$ (c) does not specify the manner in which this right can be exercised. It thus leaves to the Contracting States the choice of the means of ensuring that it is secured in their judicial systems, the Court's task being only to ascertain whether the method they have chosen is consistent with the requirements of a fair trial. In this respect, it must be remembered that the Convention is designed to "guarantee not rights that are theoretical or illusory but rights that are practical and effective" and that assigning counsel does not in itself ensure the effectiveness of the assistance he may afford an accused (see Imbrioscia, cited above, § 38).

52. National laws may draw consequences from the attitude of an accused in the initial stages of police interrogation that could be decisive for the defence of the accused in any subsequent criminal proceedings. In such circumstances Article 6 will normally require that the accused be allowed to benefit from the assistance of a lawyer in the initial stages of police interrogation. However, this right has so far been deemed to be subject to restrictions for good cause. The question is therefore whether such restriction is justified in each individual case and whether in the light of the proceedings as a whole such a restriction does not deprive the accused of a fair hearing, for even a justified restriction can do so in certain circumstances (see John Murray, cited above, $\S 63$; Brennan, cited above, $\S 45$; and Magee, cited above, $\S 44)$.

Despite the motives found in these paragraphs of the Salduz case, the rules proposed in the first draft bill have been overtaken by developments in the other source of European law relevant to the Netherlands, the European Union: as a result of the Salduz verdict, explaining Article 6 of the ECHR in a more elaborate way, the European Union institutions found grounds to propose a Directive with the objective of setting minimum standards in all the Member States for the right of access to a lawyer, the right to communicate with a lawyer after arrest, and the right to have a third party

25. ECHR 23 November 1993, Series A No. 277A, Poitrimol v. France.

26. ECHR 28 February 2008, Appl. No. 68020/01, 28 February 2008, Demebukov v. Bulgaria. 
informed upon deprivation of liberty. ${ }^{27}$ This proposal was done as part of the 'roadmap' strengthening procedural rights of suspects and accused persons in criminal proceedings. $^{28}$ These common minimum rules should lead to increased confidence in the criminal justice system of all Member States, which in turn should contribute to more efficient judicial cooperation on the legal basis of mutual trust. ${ }^{29}$ After having discussed a few concept versions, the adopted version of the Directive, $\mathrm{Pb}$ EU 2013, L 294, was published in the Official Journal of the EU on 6 November 2013. ${ }^{30}$ The first striking element of the Directive is that it offers fewer possibilities for the Member States to limit or defer the right of access to a lawyer than offered by the ECtHR in its interpretation of the right of access to a lawyer.

The first, initial, Dutch draft bill on legal assistance and police interrogation also had another remarkable aspect. This first draft proposal argued that adequately regulating legal assistance prior to and during police interrogation in the primary stage of an investigation and criminal proceedings required changes in the system of custodial measures to which suspected or accused persons can be submitted as well. In the Netherlands, with regard to criminal law, the emphasis is currently largely placed on a quick trial in court and the imposition of measures depriving a person of his liberty by the judge. In the Netherlands the relatively long period of deprivation of liberty without the involvement of a judge is a matter that has several times led to questions as to whether or not Dutch legislation in this field conflicts with the rights laid down in Article 5 of the ECHR. The first draft bill also aimed to adjust and improve this aspect of criminal proceedings in the Netherlands to bring it in to line with the standards of the ECHR and the ECtHR, but these aspects are now, as mentioned earlier, regulated in a separate draft bill proposal.

As mentioned earlier, the first draft was altered and divided into two separate draft bills. The division of the proposal into two separate drafts as well as the modifications and changes of the regulations were related to the adoption of Directive, Pb EU 2013, L 294. Apparently, the conclusion was drawn that the initial draft proposal did not meet the requirements set out in the Directive. The question whether the scope of the first Dutch proposal reached far enough to appease the more farstretching Directive of the European Union on the right of access to a lawyer in criminal proceedings and on the right to communicate upon arrest arose in particular. ${ }^{31}$

27. Directive 2013/48/EU, 22 October 2013, Pb EU L249, introduction para. 1 refers to Art. 47 the Charter of Fundamental Rights of the European Union (the Charter).

28. Adopted by the Council on 30 November 2009, OJ C 295, 4 December 2009, at 1.

29. Proposal for the Directive of the European Parliament and of the Council on the right of access to a lawyer in criminal procedures and on the right to communicate upon arrest, 11497/11, preambule (9), at 5.

30. OJ, Directive Pb EU 2013, L 294.

31. See amongst others: the pre-advice of the 'Adviescommissie Strafrecht inzake conceptwetsvoorstel rechtsbijstand en politieverhoor', at 3.
The new draft proposal, replacing the first draft bill partially, with a focus on implementing the EUDirective, $\mathrm{Pb}$ EU 2013, L 294, is supposed to meet the requirements set out by the EU-Directive as well as the standards following from the verdicts of the ECtHR on this matter.

Now the question arises whether or not the new, second draft bill, the one that sets out to implement the EU-Directive, meets the standards set out in the EUDirective, in particular those standards considered to be common minimum rules for all Member States. Since the presence of a lawyer prior to and during police interrogation has the largest impact on the current criminal proceedings in the Netherlands, this article will place emphasis on those rights. In order to provide an answer to this question, the following paragraph discusses the substance of the Directive, Pb EU 2013, L 294, regarding the presence of a lawyer prior to and during police interrogation. Other aspects of the Directive such as the right to appoint a lawyer in a Member State as a part of European Arrest Warrant proceedings or the possibility for a suspect to inform a third party of the deprivation of liberty and to communicate with a third party and consular authorities will be discussed briefly. Next, the new proposed draft bill, drafted to implement the aforementioned Directive, will be discussed. After that, an assessment will be made whether or not the standards as set out in the Directive are met. Besides that, some remarks on the verdict of the Supreme Court concerning the presence of the lawyer during police interrogation will be discussed. The paper concludes with the findings of this research.

\section{Substance of the Directive}

The Directive regards the right of access to a lawyer during criminal proceedings and the right to communicate upon arrest ${ }^{32}$ (hereafter: the Directive). Since this paper will focus primarily on the presence of a lawyer during police interrogation resulting from the Salduz verdict and this Directive, the outline of the Directive will be limited to the right of access to a lawyer during criminal proceedings involving adult suspects or accused persons and the related duty to provide information pursuant to the Directive. For the sake of clarity, this paragraph briefly summons up the substance of the provisions in the Directive to enable a comparison to be made with the (newly) draft bill in the next part of this paper.

The Directive of the European Union on the right of access to a lawyer in criminal proceedings and the right to communicate upon arrest comprises 18 articles which address the subject in groups. The first two articles contain the definition of the subject as well as the scope of the Directive. The objective of the Directive is to create common minimum rules in the entire European Union

Directive 2013/48/EU, 22 October 2013, Pb EU L249. 
regarding the rights of suspects and accused persons and persons submitted to execution determined in the Council Framework Decision 2002/584/JHA (European Arrest Warrant) on the right to access to a lawyer, to inform a third person of the deprivation of liberty, and the right to communicate with third persons and consular authorities during the deprivation of liberty. ${ }^{33}$ The background to the Directive, as already highlighted in the introduction, is reflected in this objective. Although the objective of the Directive is indeed to strengthen the procedural guarantees of the accused, it should be borne in mind that it (also) does so with a view to further strengthening and facilitating judicial cooperation between the Member States of the European Union based on the principle of mutual recognition. This objective of strengthening judicial cooperation is not the same as the 'pure' human rights context of the ECHR and the case law of the ECtHR.

The Directive applies to suspects or accused in a criminal investigation from the moment they are informed of a suspicion raised against them by the competent authorities of a Member State. This information may be given in the form of an official notification, but can be effected in other ways as well. Regardless the question of whether the person in respect thereof has been deprived of freedom it applies, although the right to legal assistance is of course particularly intended for this category of suspects. According to its text, the rights of the Directive continue to apply until the completion of the investigation, which is the final determination of the question whether the suspected or accused person has committed the offence. This includes, if applicable, sentencing and treatment of the criminal appeal proceedings (for the Netherlands, the appeal, the appeal in cassation, and partly review, both favourable and unfavourable in particular). ${ }^{34}$

The Directive shall also apply to persons subject to the implementation of the European Arrest Warrant from the moment they are held in the implementing Member State, in the manner laid down in this Directive. ${ }^{35}$ The provisions on the application of the Directive also laid down in Article 2 are of some practical importance; the rights under these provisions are also applicable, under the same conditions as referred to in the first paragraph, to persons who are not (initially) questioned as a suspect or accused but who come to be regarded as a suspect or accused during the course of the interrogation by police or other competent authorities as well.

Of greater importance, most certainly for the Dutch situation, are the provisions of the fourth paragraph of Article 2. In case of 'insignificant facts', and without prejudicing the right to a fair trial, this paragraph applies if no custodial sentence can be imposed as a sanction, or if under the laws of a Member States, jurisdiction to impose sanctions can be mandated to

33. Directive 2013/48/EU, 22 October 2013, Pb EU L249, Art. 1.

34. Directive 2013/48/EU, 22 October 2013, Pb EU L249, Art. 2, para. 1.

35. Directive 2013/48/EU, 22 October 2013, Pb EU L249, Art. 2, para. 2 and Art. 10. authorities other than the judiciary, and if they impose sanctions, those sanctions can be challenged in court. This Directive is only applicable to criminal court cases, containing investigative proceedings conducted by or on behalf of the court as well. Nevertheless, the Directive is fully applicable if the suspect or accused person is deprived of liberty, regardless of the stage or phase of the investigation. ${ }^{36}$

The second group of articles in this Directive is of vital interest for this paper, namely, Article 3 and Article 4 of the Directive, with the primary focus on Article 3 which deals with the right of access to a lawyer and, more specifically, the matter of having a lawyer present during police interrogation. When and if actual communication between the suspect or accused and his lawyer takes place, it goes without saying that this communication and its content should be confidential and should be treated as such, according to Article $4 .{ }^{37}$ Since the matter of confidentiality as set out in the Directive does not require any amendments in Dutch legislation nor leads to any such amendments in the proposed Dutch draft bills, we will not discuss the content of this article in this paper. Article 3 obligates every Member State to ensure that suspects and accused persons have the right of access to a lawyer at such a time and in such a manner so as to allow the person concerned to exercise his rights of defence practically and effectively. ${ }^{38}$ They shall have access to a lawyer without undue delay. In any event, they shall have access to a lawyer from, whichever comes first, the moment before he or she is questioned by police or other enforcement or judicial authorities or upon the carrying out of an investigative or other evidence-gathering act by an investigative or other competent authority, from the deprivation of liberty without undue delay or in due time before the suspect or accused person appears before the court, having been summoned to appear before that court having jurisdiction in criminal matters. ${ }^{39}$

The right of access to a lawyer contains the notion that the Member State has to ensure that a suspect or accused person has the right to meet in private and communicate with the lawyer representing him, prior to questioning by the police or other judicial or lawenforcing authorities. ${ }^{40}$ During questioning of the suspect or the accused, the lawyer shall have the right to be present and participate effectively. His participation can be regulated by procedures in national law, as long as these procedures themselves do not prejudice the effective exercise and essence of this right. In accordance with national law, the participation of the lawyer shall be recorded. ${ }^{41}$ The suspect or the accused has, as a minimum, the right for their lawyer to attend the following

\footnotetext{
36. Directive 2013/48/EU, 22 October 2013, Pb EU L249, Art. 2, para. 4.

37. Directive 2013/48/EU, 22 October 2013, Pb EU L249, Art. 4

38. Directive 2013/48/EU, 22 October 2013, Pb EU L249, Art. 3, para. 1

39. Directive 2013/48/EU, 22 October 2013, Pb EU L249, Art. 3, para. 2.

40. Directive 2013/48/EU, 22 October 2013, Pb EU L249, Art. 3, para. 3 under a.

41. Directive 2013/48/EU, 22 October 2013, Pb EU L249, Art. 3, para. 3 under $b$.
} 
investigative or evidence-gathering acts, if provided by national law, and he is required or permitted to attend: identity parades, confrontations, or experimental reconstructions of the scene of the crime. $^{42}$ General information to facilitate suspects or accused persons in obtaining a lawyer should be made available as well as the necessary arrangements, notwithstanding provisions of national law concerning the mandatory presence of a lawyer, to ensure that suspects or accused persons, deprived of their liberty, shall be in a position to effectively exercise their right of access to a lawyer, unless they have waived this right in accordance with Article $9 .{ }^{43}$

Temporary derogations from the application to consult a lawyer after the deprivation of liberty may only be made in the pre-trial stage in exceptional circumstances, when the geographical remoteness of a suspect or accused person makes it impossible to ensure this right. ${ }^{44}$ From the application to gain access to a lawyer to meet with him in private, communicate with him and have him present at the questioning by the police as well as investigative or evidence-gathering acts, temporary derogations can only be made, in exceptional circumstances, when this is justified and to the extent that this is or can be perceived as justified in the light of the particular circumstances of the case, by one or more compelling reasons, such as an urgent need to avert serious adverse consequences for the life, liberty or physical integrity of a person or an imperative immediate action preventing a substantial jeopardy to criminal proceedings by investigative authorities. ${ }^{45}$

The next group of articles, Articles 5, 6, and 7, regulate the right of informing a third person of the deprivation of liberty and communication with a third person and consular authorities. These articles of the Directive do not affect current Dutch legislation and like Article 4 of the Directive have not led to any proposals to change current legislation in the Dutch draft bills; therefore, these articles will not be discussed at this moment.

An important part of the Directive is formed by the following group of articles, Articles 8 and 9, which deal with derogations and waivers. Article 8 formulates general conditions for applying the (sole) temporary derogations allowed to infringe the right of access to a lawyer (Article 3) on the basis of subparagraph 5 or 6 of that article exclusively. Such temporary derogations in all cases have to be proportionate and should not go beyond what is necessary. The limitations shall be strictly limited in time, shall not exclusively be based on the type or the seriousness of the alleged offence, and shall not prejudice the overall fairness of the proceedings. ${ }^{46}$ Temporary derogations with regard to the insurance that suspects and accused persons have a right of access to a lawyer in such a manner so as to allow the person concerned to exercise his rights of defence practically and effectively may only be authorised by a judicial authority or other competent authorities on the ground of the particular case by a duly reasoned decision. This decision shall be open for submission to a judicial review. The duly reasoned decision shall, in accordance with national law, be recorded. ${ }^{47}$ Temporary derogations with regard to having a third person informed of the deprivation of liberty can only be authorised either by a judicial or other competent authorities on the ground of a particular case on condition that this decision can be submitted to judicial review. ${ }^{48}$

It is rather remarkable, as such, that the Directive leaves room for a waiver of the right of access to a lawyer, as meant in Article 3. One might argue, as mentioned in the introduction, that the background of introducing this right consists of rather different reasons. As it is broadly accepted that a suspect or an accused person has the right to organise his defence in the way that he considers to be best (an approach to rights of the defence which makes the use of waivers acceptable); nevertheless, it must be held into consideration, as spoken of earlier, that the right of access to a lawyer also fulfils a function in the prevention of ill-treatment and in the prevention of miscarriages of justice. Seen against the background of the latter, a waiver of his rights from the accused before he is interrogated by the police for instance can be open for debate.

Nevertheless, if a waiver of this fundamental right is accepted as such, it can be considered as rather wise that the Directive actually formulates the conditions which legitimate waivers, as is done in Article 9. In relation to the waiver of a right referred to in Article 3 (or 10), it is ensured, without prejudice to the national law, requiring mandatory presence or assistance of a lawyer, that a suspect or accused is provided with clear and sufficient information in simple and understandable language about the content of the right concerned and possible consequences of the waiver of this right. This information can be provided orally or written. Next to that, the waiver has to be given voluntarily and unequivocally by the suspect or accused person. ${ }^{49}$ Temporary derogations with regard to having a third person informed of the deprivation of liberty can only be authorised either by a judicial or another competent authority on the grounds of the particular case on condition that this decision can be submitted to judicial review.

The circumstances under which the waiver, made orally or in writing, was given shall be noted in accordance with national law. ${ }^{50}$

The waiver can be revoked at any point during the criminal proceedings, and the suspect or accused person shall be informed about this possibility. The revocation comes into effect from the moment in time the revoca- 
tion is made. ${ }^{51}$ From that moment on, the effect will only be prosperous; in principle, it does not make earlier statements under the waiver illegal nor does it exclude the use of earlier statements made under the waiver as such, as evidence against the suspect or the accused.

Article 10 deals with European Arrest Warrant proceedings. It generally states that the rights provided for in this Directive shall also apply in the case of a procedure in accordance with a European Arrest Warrant.

The final group of articles in the Directive contains the rather usual regulations in Directives concerning legal aid, remedies, non-regression clauses, adaptation of the Directive in national law, and the addressees. The content of a few articles in this category is of particular interest, with regard to the central issue of this paper: the access of a lawyer prior to and during police interrogation in present and future Dutch law. Article 12, on remedies, obliges the Member State to ensure that the suspect or accused persons in criminal proceedings as well as requested persons in European Arrest Warrant proceedings have, where their rights under this Directive have been breached, an effective remedy under national law. A Member State ensures that, without prejudice to national rules on systems on the (in-)admissibility of evidence in criminal proceedings, in the assessment of statements made by a suspect or accused person or evidence obtained in breach of his right to a lawyer or in cases where a derogation to this right was authorised in accordance with Article 3, paragraph six, the rights of the defence and fairness of the proceedings are respected. ${ }^{52}$ This article is of particular interest, since the sanction that follows on the breach of this right is the immediate exclusion of that statement for use in evidence. Whether or not these statements made under the infringements of rights is left to the national law of the Member States, the Directive as such does not oblige Member States to sanction the breach of this right with exclusion of evidence. Neither the ECHR nor the rulings of the ECtHR recognise the exclusion of unlawfully obtained evidence as a general necessary sanction; e.g., the use of evidence obtained in breach of Article 8 of the ECHR, as such, does not immediately lead to the conclusion that there has been a breach of the fair trial principle per se. ${ }^{53}$ But the specific right of the accused to have access to a lawyer has a slightly different nuance. In the explanatory memorandum of the Directive (section 50), it is correctly pointed out that case law of ECtHR provides that the rights of the defence are in principle irrevocably violated when incriminating statements made during a police interrogation in absence of a lawyer are used as evidence against the accused. Such violation of rights, regarded as highly fundamental, can - within this context - imply less to nothing than the exclusion of evidence obtained directly on the basis of such violation. Therefore, it is lamenta-

51. Directive 2013/48/EU, 22 October 2013, Pb EU L249, Art. 9, para. 3

52. Directive 2013/48/EU, 22 October 2013, Pb EU L249, Art. 12, para. 2 under a.

53. As follows amongst other from ECHR 27 April 2004, Appl. No. 50210/99, Doerga v. the Netherlands. ble that, although the Directive does not contain an explicit mandate to respect the law of the ECtHR, ${ }^{54}$ it does not reach further, as, for example, Article 15 of the UN anti-torture convention does, by explicitly prescribing that such evidence should be excluded. ${ }^{55}$ In the following part of this paper, we will examine to which extent further form and content is given in the Netherlands to the exclusion of statements made by an accused person, as evidence when it is established by the judge that these statements were obtained violating the right of the accused under the Directive as discussed above.

For the right to access to a lawyer and to communicate with him prior to, during, as well as after the police interrogation, Article 13, in particular, is of interest. The content of the article in the Directive in itself is limited. It obligates a Member State to ensure that in the application of the Directive the particular needs of the vulnerable suspects and vulnerable accused persons are taken into account. The implications of this short content could be much wider reaching however. The general principle, laid down in paragraph 51 of the explanatory memorandum, is rather strict and fundamental. The prosecuting authorities in relation to suspects and accused in a potentially weak position have an (additional) duty. The observation of this is the basis of a fair administration of justice. Conversely, fair administration of justice means, after all, that measures must be taken to provide assistance in case of individual inability on the part of specific suspects to exercise their own rights properly. This requires additional facilities to enable the actual exercising and realisation of the rights under the Directive vis-à-vis this particular group of suspects as well. If we limit ourselves to criminal proceedings against adult suspects and accused, then in particular the suspect or accused with a certain degree of mental illness, whether or not due to an addiction, is important. Traditionally this concerns a relatively large group amongst the arrested suspects or accused. What should the duty of care towards them entail? To us, within this context, it seems that in the first place of realising the right of access to a lawyer from the moment this right arises, judicial authorities must recognise that a particular case involves a vulnerable suspect. Recognition, also based on adequate training and experience, is the first phase in performing this duty of care. Next, an appropriate decision based on this recognition should (be able to) be taken as to the extent in which the suspect is able to understand and exercise his rights. Where too much doubt about this exists, in particular during the first police interrogation, there must be adequate provisions for calling in an expert at any time, if so desired. This could include a system in which the police can use emergency mental health services. The question

54. According to the usual non-regression clause (Art. 14 of the Directive), nothing in the Directive shall be construed as limiting or derogating from any rights and procedural safeguards that are ensured under the Charter, the ECHR, and other relevant provisions of international law or higher level of protection provided by the law of any Member State.

55. Convention against Torture and other Cruel, Inhumane or Degrading Treatment or Punishment of 10 December 1984, Trb. 1985, 69. 
arises as to whether it is possible to always arrange these facilities in the first phase of the criminal investigation, the (first) interrogation of the (detained) accused, sufficiently. Where, perhaps as the result of such a procedure, (too) many doubts exist regarding the suspects' or accused persons' capacity to understand his rights and to (actually and effectively) exercise these himself, his right of access of a lawyer should be (able to be) replaced by a system in which the lawyer can exercise the rights on his behalf (see for the Dutch situation Article 509a of the Dutch Code of Criminal Procedure). As this decision is very drastic, one should wonder whether or not this decision should not be reserved exclusively to a court. The duty of care may also include the decision whether or not trial and punishment is the most appropriate course of actions for the vulnerable suspect. Possibly it could be better for the vulnerable suspect to channel him through the civil mental health facilities because of, for example, serious doubts as to his culpability or his 'fitness' to stand to trial. Be that as it may, in all cases attention for vulnerable persons will be of vital importance if a waiver of the rights given by this Directive, based on Article 9, is made.

Such a waiver is only legitimate if it is established with sufficient understanding of the issue, with an understanding of the consequences of the waiver, and with sufficient free will. In the event of a waiver by a vulnerable person, timely and adequate attention must be paid to ensure that these conditions are met at the time the waiver is made. In this context, it is important to mention that the second paragraph of Article 9 provides that the circumstances under which the waiver is made are recorded. It is very important, on this point, that due care is exercised in relation to the rights under the Directive for vulnerable persons. After all, if too many doubts remain as to whether the special needs of vulnerable persons, as required under Article 13 of the Directive, have been met or arise afterwards, this means a violation of the Directive and the right of access to a lawyer, which can often lead to the exclusion of the statement made by the vulnerable person, in other Member States in case of cooperation in criminal matters and in national cases even after a criminal case has already been closed by a final court ruling. ${ }^{56}$ This can also harm the interests of criminal justice. In fact, it is precisely because the Directive aims, by protecting and shaping the right of access to a lawyer, to contribute to the further strengthening and realisation of mutual cooperation in criminal cases within the EU Member States on the basis of the principle of mutual recognition, which makes it imperative that in appropriate cases sufficient attention is paid to this issue in the requested state, in order to prevent the arising of later difficulties in and under the national law of the requesting state, as far as further prosecution of the suspect or accused per-

56. See for an example for the Netherlands: Dutch Supreme Court 29 October 2013, ECLI:NL:HR:2013:1070; the fact that at the time of making his statement of confession a suspect may have been suffering a psychosis could be considered a reason to revise the previously given, irrevocable sentence. son is concerned. Of course, within that context, the registration prescribed in Article 9 of that which has occurred in requested state is of interest as well.

The second Dutch response towards the abovementioned rights, as laid down in the Directive, will be discussed in the following paragraph. Describing the rights as laid down in the draft following the initial first draft will enable us to determine whether or not the aims of the Directive are met by the Dutch legislator.

\section{The Second Proposed Draft Bill}

As stated above, the first draft bill on legal assistance and police interrogation aiming to amend Dutch criminal procedure law was presented by the Ministry of Security and Justice on 22 March 2011. This first draft bill amending the Dutch Penal Code addressed several parts and aspects of criminal proceedings in the Netherlands. On one hand, it focused on enabling the lawyer to be present prior to, during, and after the police interrogation, and on the other hand, its focus was on changing the criminal procedures with regard to the deprivation of liberty in the first phases of the criminal investigation.

As explained in the introduction of this paper, the first draft bill intending to transpose the rights, reflecting the developments within the Council of Europe and the European Union, was to be founded on the Guidelines of the Public Prosecution referred to above and, also referred to earlier, on the results from experiments in police interrogation with a lawyer present. This first draft bill however was drafted long before the Directive was established by the Member States of the EU. As mentioned earlier, the establishment of the EUDirective, as well as the restrained approach of the matter by the Dutch government and institutions, created arguments to divide the first draft proposal into two amended draft proposals: one with a focus on implementing the established European Union Directive and one to process the changes in the criminal proceedings in the first phase of the criminal investigation in Dutch Criminal Proceedings.

This paper primarily has a focus on the regulation of legal assistance of (adult) suspects prior to, during, and after police interrogation. This paragraph provides an overview of the substance of the second proposed draft bill aiming on the implementation of the European Directive and defines the framework the Dutch legislator has set out in transposing the Directive into national regulation.

As far as the grounds for the right to legal assistance during police interrogation are concerned, the draft bill is in line with the choice made by European law. In other words, unlike current Dutch rules governing criminal proceedings, the new rules provide for the extensive regulation of legal assistance for the suspect or accused 
prior to and during police interrogation. The arrest of a suspect or an accused person with a view to interrogation is, under Dutch criminal law, the first stage in the deprivation of liberty by the police under the authority of the public prosecutor. Dutch Criminal Proceedings do not provide for a writ of 'habeas corpus'.

Article 1 of the second draft bill proposes the amendment of the earlier proposed, however not yet adopted Article 27c CPC, which will require that suspects or accused persons are provided with certain information in the criminal procedures. ${ }^{57}$ The amendment of the proposed article will mean that information given to a suspect deprived of his liberty should also entail the information on the possibility of informing a third person as well as consular authorities of the deprivation of liberty. ${ }^{58}$ Next to the extension of the earlier proposed article, Article 27c CPC, the second draft bill proposes two new articles: Article $27 \mathrm{~d}$ and 27e CPC. The first contains the requirement to remind the person of the capacity in which he is being heard in case of an invitation to come to make a statement to the police, either at the police station or over the phone. ${ }^{59}$ If a suspicion towards a person heard as witness arises, the interrogating police officer should notify the person of the rights mentioned in the first two paragraphs of Article $27 \mathrm{c}$ CPC. ${ }^{60}$ The second, Article 27e CPC, obliges the deputy public prosecutor ${ }^{61}$ to inform without delay, at least one person appointed by the suspected, about the deprivation of liberty. ${ }^{62}$ If a suspect or accused person does not have the Dutch nationality, the deputy public prosecutor informs the consular authorities of his nationality. ${ }^{63}$ Informing the appointed third party on the deprivation of liberty of the suspect can be delayed if the delay can be perceived as justified by one or more compelling reasons, such as an urgent need to avert serious adverse consequences for the life, liberty, or physical integrity of a person or an imperative immediate action preventing a substantial jeopardy to criminal proceedings by investigative authorities. ${ }^{64}$

The proposed new first paragraph of Article 28 forms an introduction on the newly shaped regulation of assis-

57. Art. 27c was proposed on 13 February 2014 and has passed the Tweede Kamer (House of Representatives), and the bill is currently submitted to a parliamentary committee of the Eerste Kamer (Senate), Parliamentary Papers II, 2014-2015, 33871, No. 5.

58. Second draft Bill on implementing the EU-Directive 2013/48/EU (PbEU L294), Art. 27c, para. 3 under g and h.

59. Second draft Bill on implementing the EU-Directive 2013/48/EU (PbEU L294), Art. 27d, para. 1

60. Art. 27c has, as mentioned, not yet entered into force; following Parliamentary Papers II, 2014-2015, 33871, the proposed first two paragraphs of Art. 27c CPC refer to the right to be notified of which offence he is a suspect, the right for a suspect with insufficient command of the Dutch language to be assisted by an interpreter, and the right to make effective use of his right to legal assistance.

61. Usually a higher-ranked officer of police, not necessarily a member of the Public Prosecution Service

62. Second draft Bill on implementing the EU-Directive 2013/48/EU (PbEU L294), Art. 27e, para. 1.

63. Second draft Bill on implementing the EU-Directive 2013/48/EU (PbEU L294), Art. 27e, para. 2

64. Second draft Bill on implementing the EU-Directive 2013/48/EU (PbEU L294), Art. 27e, para. 3. tance by a lawyer, as laid down in the proposed Articles 28a till 28d CPC. ${ }^{65}$ Article 28a, first paragraph, gives the suspect the option to waive his right consciously and voluntarily, unless the Criminal Procedure Code dictates otherwise. Whether the suspect acted voluntarily is of prime interest. No pressure whatsoever may be put on him to waive his rights as this could later support allegations that the defence was involuntarily. Under the Dutch Criminal Proceedings, it is up to the judge to decide whether or not these conditions were met. The second paragraph of the proposed article is of interest in this context. A suspect can only make a waiver of his right mentioned in the firstparagraph, if he is informed about the consequences of this waiver by a judge or a police officer and informed on the fact that he can withdraw the waiver at any time. If a waiver is made, a report of such shall be made in the minutes. The regulations make no mention of reporting the circumstances under which the waiver came about, a report which could be of interest with a view to the (judicial) review of the conditions of voluntariness and consciousness, as required by regulations regarding the waiver itself. The memorandum states explicitly that information provided once stands as sufficient. ${ }^{66}$

Contrary to the first proposed draft bill, this second draft offers regulations regarding vulnerable persons as well as suspect of crimes punishable with a maximum of twelve or more years of imprisonment. If a suspect is vulnerable or under suspicion of a crime punishable with a maximum of twelve years or more of imprisonment, the deputy public prosecutor informs the board of the Council of Legal Assistance, so that the board provides actual legal assistance by a lawyer. ${ }^{67}$ The board of the Council of Legal Assistance is also informed in case a suspect, who has not chosen a lawyer and desires to have legal assistance, is arrested for a crime for which pre-trial detention is allowed. In this case the board will designate a lawyer to the suspect. ${ }^{68}$ If the suspect desires legal assistance in case the arrest is for a crime for which pre-trial detention is not allowed, he will be, at his request, given the opportunity to make a phone call with a lawyer and communicate with him. ${ }^{69}$

Rather remarkable is the fact that a lawyer in principle has to be present and available for legal assistance within two hours. If he is not available within that time limit, the deputy public prosecutor can decide to start with interrogating of the suspect without the lawyer present. The deputy public prosecutor can stretch the men-

65. Second draft Bill on implementing the EU-Directive 2013/48/EU (PbEU L294), Art. 28, para. 1.

66. Explanatory Memorandum 2nd draft Bill on implementing the EUDirective2013/48/EU (L 294), at 66-67.

67. Second draft Bill on implementing the EU-Directive 2013/48/EU (PbEU L294), Art. 28b, para. 2

68. Second draft Bill on implementing the EU-Directive 2013/48/EU (PbEU L294), Art. 28b, para. 3.

69. Second draft Bill on implementing the EU-Directive 2013/48/EU (PbEU L294), Art. 28b, para. 3. 
tioned limit, on request of the lawyer, without detaining the investigation. ${ }^{70}$

If a lawyer, following Article 28b, is available, the suspect is offered the right to communicate with him prior to the first interrogation by police for half an hour. ${ }^{71}$ With authorisation of the public prosecutor, the deputy public prosecutor can decide that the interrogation starts within the time limit of two hours, offered to the lawyer to be present at interrogation, or refuse the right to communicate with a lawyer for half an hour, as laid down in the first paragraph of this article, when this can be perceived as justified by one or more compelling reasons, such as an urgent need to avert serious adverse consequences for the life, liberty, or physical integrity of a person or an imperative immediate action preventing a substantial jeopardy to criminal proceedings by investigative authorities. ${ }^{72} \mathrm{~A}$ waiver of the right to communicate with a lawyer prior to the interrogation by vulnerable suspects as well as suspects of crimes punishable with a maximum of twelve or more years of imprisonment can only be done after the accused concerned is informed of the consequences of this waiver by a lawyer prior to the waiver being made. ${ }^{73}$ Thus with these kinds of suspects, there always has to be contact between the lawyer and the suspect prior to the first police interrogation.

The lawyer has the right to be present during police interrogation and participate in the interrogation, at the request of the arrested or invited suspect. The request is made to the interrogating officer or the deputy public prosecutor. The latter can reject a request to interrupt interrogations, if repeated requests disturb the order or the progress of the police interrogation. The lawyer's presence and participation to the interrogation will be reported in the minutes. ${ }^{74}$

With prior authorisation of the public prosecutor, the deputy public prosecutor can refuse to give a lawyer access to the interrogation when this can be perceived as justified by one or more compelling reasons. These compelling reasons are equal to the grounds on which the right to communicate with a lawyer prior to the interrogation can be denied. ${ }^{75}$ During police interrogation without a lawyer present, the suspect can request interruption of the interrogation in order to consult with his lawyer. The request is granted as often as possible unless the repeated requests disturb the order and progress of the interrogation. ${ }^{76}$ The drafter considered the

70. Second draft Bill on implementing the EU-Directive 2013/48/EU (PbEU L294), Art. 28b, para. 4.

71. Second draft Bill on implementing the EU-Directive 2013/48/EU (PbEU L294), Art. 28c, para. 1.

72. Second draft Bill on implementing the EU-Directive 2013/48/EU (PbEU L294), Art. 28c, para. 2

73. Second draft Bill on implementing the EU-Directive 2013/48/EU (PbEU L294), Art. 28c, para. 3

74. Second draft Bill on implementing the EU-Directive 2013/48/EU (PbEU L294), Art. 28d, para. 1.

75. Second draft Bill on implementing the EU-Directive 2013/48/EU (PbEU L294), Art. 28d, para. 2.

76. Second draft Bill on implementing the EU-Directive 2013/48/EU (PbEU L294), Art. 28d, para. 3. fact that criminal proceedings are best served by an uninterrupted interrogation as a ground to give the investigative authorities this power. ${ }^{77}$ Exercising the powers to deny communication and consultation prior to and during interrogation is to be immediately reported to the public prosecutor by the deputy public prosecutor. This decision only applies to the interrogation in which they were made, the grounds on which they were founded shall be mentioned in the minutes. ${ }^{78}$ When the lawyer is denied access for the interrogation, this should be recorded in a manner determined by the implementing rules. ${ }^{79}$ The implementing rules can set out general rules on the manner and order of interrogations. ${ }^{80}$

After the four articles drafting the general shape of legal assistance prior to and during interrogation, the draft sums up an article dealing with the Council for Legal Assistance and articles providing rules for a specific group of vulnerable persons.

After being informed by the deputy public prosecutor of an arrest of suspects referred to in the first two paragraphs of Article 28b, as well as a notification of a detention in police custody of a suspect who did not appeal for legal assistance until that moment, the board of the Council for Legal Assistance immediately provides the suspect with a lawyer. ${ }^{81}$ In order to provide the suspect with a lawyer as soon as possible, a list of registered lawyers is used. ${ }^{82}$ Preferences for a specific lawyer are taken into account by the Council. ${ }^{83}$ In case no lawyer is present nor available in time, the deputy public prosecutor or the public prosecutor informs the Council immediately in order to make sure the suspect is provided with a lawyer ${ }^{84}$ During the appeal of the public prosecution of an immediate release order, the provided registered lawyer represents the suspect as well. The provision of the lawyer ends when the accused is arrested, with the ending of the investigation as well as (extended) detention in police custody. ${ }^{85}$

When a minor is involved, the deputy public prosecutor informs the suspect's parents or custodian as soon as possible after the arrest and of the reasons thereof. ${ }^{86}$ Informing the parents or custodian on the deprivation of liberty of the suspect can be delayed for the same rea-

77. Explanatory Memorandum 2nd draft Bill on implementing the EUDirective2013/48/EU (L 294), at 48.

78. Second draft Bill on implementing the EU-Directive 2013/48/EU (PbEU L294), Art. 28d, para. 4.

79. Second draft Bill on implementing the EU-Directive 2013/48/EU (PbEU L294), Art. 28d, para. 5.

80. Second draft Bill on implementing the EU-Directive 2013/48/EU (PbEU L294), Art. 28d, para. 6.

81. Second draft Bill on implementing the EU-Directive 2013/48/EU (PbEU L294), Art. 40, para. 1.

82. Second draft Bill on implementing the EU-Directive 2013/48/EU (PbEU L294), Art. 40, para. 2.

83. Second draft Bill on implementing the EU-Directive 2013/48/EU (PbEU L294), Art. 40, para. 3.

84. Second draft Bill on implementing the EU-Directive 2013/48/EU (PbEU L294), Art. 40, para. 4.

85. Second draft Bill on implementing the EU-Directive 2013/48/EU (PbEU L294), Art. 40, paras. 5 and 6 .

86. Second draft Bill on implementing the EU-Directive 2013/48/EU (PbEU L294), Art. 488b para. 1. 
sons as not informing a third party, mentioned earlier. If there is an actual delay, the deputy public prosecutor immediately informs the Council for Child Protection. ${ }^{87}$ Finally the deputy public prosecutor informs the board of the Council for Legal Assistance on the arrest of a vulnerable suspect to ensure the board provides the suspect with a lawyer. ${ }^{88}$ After being informed by the deputy public prosecutor of the arrest, the board of the Council for Legal Assistance immediately provides the suspect with a lawyer. ${ }^{89}$ The deputy public prosecutor has a possibility to start interrogation within the time limit of two hours or refuse the right to communicate with the lawyer prior to the interrogation with vulnerable person as well. The delay can be perceived as justified by one or more compelling reasons, such as an urgent need to avert serious adverse consequences for the life, liberty, or physical integrity of a person or an imperative immediate action preventing a substantial jeopardy to criminal proceedings by investigative authorities. ${ }^{90}$ The lawyer provided by the board of the Council for Legal Assistance provides the vulnerable suspect with assistance. The vulnerable suspect cannot waiver the right to communicate to the lawyer prior to the interrogation. During his conversation with the lawyer, the necessity of his presence during interrogation is discussed. The deputy public prosecutor is informed of the outcome of the conversation. On the request of the suspect, the lawyer provides legal assistance during investigation. The implementing rules can set out general rules on the manner and order of this kind of interrogations. ${ }^{91}$

Next to the described proposed articles, the draft proposal contains a few amendments to the Surrender Act. ${ }^{92}$ The amendment of these articles is related to the right to access to a lawyer in the extraditing country as well. ${ }^{93}$ A possibility which has not been explicitly regulated under Dutch Law. Whereas our focus is not on the European Warrant, these articles will not be discussed here.

In the following paragraph, a review of the draft bill in relation to the Directive, containing the minimum standards set out by the European Court of Human Rights, as far as the presence of the lawyer prior to, during, as well as after police interrogation will be made.

87. Second draft Bill on implementing the EU-Directive 2013/48/EU (PbEU L294), Art. 488b, para. 2.

88. Second draft Bill on implementing the EU-Directive 2013/48/EU (PbEU L294), Art. 488c, para. 1.

89. Second draft Bill on implementing the EU-Directive 2013/48/EU (PbEU L294), Art. 488c, para. 2.

90. Second draft Bill on implementing the EU-Directive 2013/48/EU (PbEU L294), Art. 488c, para. 3.

91. Second draft Bill on implementing the EU-Directive 2013/48/EU (PbEU L294), Art. 488c, para. 4.

92. Second draft Bill on implementing the EU-Directive 2013/48/EU (PbEU L294), at 6.

93. Explanatory Memorandum 2nd draft Bill on implementing the EUDirective2013/48/EU (L 294), at 85.

\section{Assessing the Second Dutch Draft Bill}

As mentioned earlier, the presence of a lawyer during and prior to interrogation as a principle was not immediately fully embraced by the Dutch legal authorities. The approach towards the matter has always been met with a strong reliance and confidence in the professional approach by the judicial authorities, more in particular the police force. This can be considered as one of the reasons that the amendment of the regulation of the interrogation has always been approached with the current regulation as a starting point. In the following, the second proposed Dutch draft bill will be compared to the Directive as far as the presence of a lawyer prior to and during police interrogation is concerned.

The demands set out in the first two articles of the Directive, dealing with the objective and scope of this Directive, seem to have been met in the draft bill. Roughly spoken, the objective of the draft is to meet the standards set out amongst others in the ruling of the earlier mentioned case of Salduz v. Turkey as well as Pishchalnikov v. Russia ${ }^{94}$ and Dayanan v. Turkey ${ }^{95}$ and other cases ${ }^{96}$ dealing with the presence of a lawyer prior to, during, and after police interrogation which means prevention of ill-treatment as well as the earliermentioned safeguarding of the fair trial, as meant in Article 6 of the ECHR, as a whole. It needs to be emphasised that the Directive sets minimum rules concerning the rights of the suspects and accused persons in criminal proceedings. Offering suspects or accused persons more or more extended rights is not prohibited and even encouraged.

The proposed amendment of the earlier proposed Article $27 \mathrm{c} \mathrm{CPC}^{97}$ requires that suspects are provided with certain relevant information in criminal procedures. The information provided is to be extended by the amendment. If both proposals become law, it can be said that the requirement of the Directive as to providing information from the moment in time that the suspected or accused person is made aware by the competent authorities that he is suspected or accused of having committed a criminal offence, irrespective of whether or not his liberty is deprived, is met. This also goes for persons who become a suspect during the questioning by police or other law-enforcing authorities.

\subsection{Right of Access to a Lawyer: The Draft Bill} and Articles 3 and 4 of the Directive

Articles 3 and 4, as mentioned above, require the Member State to ensure the right of access to a lawyer in such a time and manner allowing the person concerned to exercise his rights of defence practically and effectively. It seems that the Netherlands as a Member 
State has tried to fulfil this requirement in the second draft bill with the proposed Articles 28 till 28d CPC. The proposed Article $28 \mathrm{CPC}$ enables the suspect to have access to one or more lawyers. These lawyers can assist him in his case. The suspect who does not have a lawyer is appointed one or, in special cases, more than one. The suspect who does not have a chosen lawyer shall be made aware of the possibility to have one appointed. According to this article, the moment in time at which the suspect or accused person shall be informed about this right is after the arrest prior to his interrogation by the assistant public prosecutor and prior to the custody or demand of detention by the public prosecutor or his assistant.

If any investigation is performed by the investigative judge: at the first interrogation by him or the person carrying out his orders of the investigative judge. In the case of notification of appeal, the accused has to be informed by the clerk.

The assistant public prosecutor informs the Council of Legal Assistance in any case when a vulnerable suspect is arrested, or an arrest made on the count of an offence which is punishable with a sentence of twelve years or more imprisonment or on the count of an offence for which remand is allowed and the suspect did not chose a lawyer but has made clear that he wants to make use of his right to access one.

This article also appears to provide the possibility for the suspect or accused person to exercise his rights laid down in the Directive effectively and practically.

The proposed Article 28c CPC deals, as mentioned earlier, with the contact between the lawyer and the suspect or accused person. According to this article, the opportunity to communicate shall be given to the suspect with his lawyer for half an hour prior to the first police interrogation. This time limitation was already provided in the first draft and demonstrates the, earlier mentioned, perspective from which fulfilling the Directive's requirements is approached. Offering a suspect half an hour to converse with his lawyer (usually both are unacquainted) seems to be a very narrow explanation of the requirement set out in the Directive. The provision answers to the demand that access to a lawyer prior to police questioning is offered without undue delay; however, the question remains whether or not limiting the time in which this right can be exercised can be regarded as an effective and practical exercise of the right. According to the ECtHR, the suspect has to obtain effective legal assistance. This means, amongst others, that the lawyer has to be able to discuss the case, to organise the defence, to collect evidence in favour of his client, to prepare him for questioning, and to support him in his distress. ${ }^{98}$ In uncomplicated cases, the halfhour limitation will probably not lead to any problems in providing legal assistance. It leaves the suspect enough time to discuss his case and the position he should take. However, in more complex cases, this limi-

98. ECHR 13 October 2009, Appl. No. 7377/03, Dayanan v. Turkey, para 32. tation in time can be regarded as rather narrow to provide the legal assistance. Beyond efficiency, any legal arguments for the limitation in time cannot be found. Thus, it appears that this limitation might prejudice the effective exercise and essence of the right involved.

The possibility to communicate with the lawyer prior to the police interrogation can be refused when this can be perceived as justified by one or more compelling reasons. ${ }^{99}$ On the same grounds, a police interrogation can start within the period of two hours, set to await the arrival of the lawyer. ${ }^{100}$ The grounds of such a decision have to be written down in the minutes of interrogation. If disputed by the defence, the judge in the court case will have to decide whether the decision was ill-founded. Evidently not allowing communication prior to the interrogation can prejudice the effective exercise of the right of defence. However, the legal grounds on which this decision can be grounded do not appear to threaten this right in principle, only diversion or abuse of the grounds seem to create a breach.

The first and third paragraphs of the proposed Article 28d CPC state that the suspect shall be offered the possibility to communicate with his lawyer as much as possible, if he so desires and the lawyer is not present during interrogation. If the lawyer is present at the interrogation, he can participate. The suspect can request to communicate with his lawyer in private. This right corresponds with the required right in Article 3 of the Directive, enabling the suspect or accused person to meet in private and communicate with his representing lawyer. The requests to communicate with his lawyer can however under Dutch law be refused, as mentioned above, if repeated requests disturb the order and progress of the interrogation. The memorandum explicitly legitimates this power by mentioning that criminal proceedings are best served by an uninterrupted interrogation. ${ }^{101}$ It needs to be emphasised that from the investigators' perspective, every request to communicate in private with a lawyer in principle can be considered as an interruption of the progress and order of the interrogation. When the situation arises that the order and progress of the interrogation is disturbed, it is initially up to the deputy public prosecutor to decide. However, the decision will be assessed by the judge in a later phase of the process. If he rules with the decision not to allow communication with a lawyer, there will be a breach of the Directive. The investigative authorities thus need to be very careful in assessing this component: the risk of putting their own interest in first place when a request is made by the suspect is rather big.

\subsection{Presence of a Lawyer during Interrogation}

Having a lawyer present during interrogation by the police is regulated by the proposed Article 28d CP in the draft bill. According to the article, the presence of a lawyer during interrogation can be refused when this

99. Ibid., at 73

100. Following the second draft Bill on implementing the EU-Directive 2013/48/EU (PbEU L294), Art. 28b, fourth paragraph, first sentence.

101. Ibid., at 78 
can be perceived as justified by one or more compelling reasons. ${ }^{102}$ When the investigative authorities feel that an urgent necessity of the investigation prohibits the presence of the lawyer during interrogation, the public prosecutor shall be notified and the grounds on which the urgent necessity is founded are recorded in the minutes of the interrogation. Thus it is to the judge to decide whether or not the refusal of the presence was illfounded if the defence states that this was the case.

In this aspect the second draft strongly deviates from the first draft bill, which limited the presence of a lawyer to severe cases. ${ }^{103}$ Prohibiting the presence of a lawyer during interrogation is a breach of the right expressed in Article 3 of the Directive. Limiting the right of his presence to severe cases thus conflicted with the requirement of the Directive. With the current proposal, his presence can only be refused if an urgent necessity to do so exists. In that respect the new draft seems to meet the requirements of the Directive. Evidently the authorities should restrain themselves in exercising this power. ${ }^{104}$

\subsection{Waiver}

The possibility for the suspect or accused person to waive his right to communicate with his lawyer prior to, during, or after police interrogation is reflected in Article $28 \mathrm{a}$ and Article 28c, third paragraph. Vulnerable suspects or suspects arrested on the count of an offence, punishable with a sentence of twelve years or more imprisonment, can only waive this right after having been informed by a lawyer of the consequences thereof. Suspects that do not belong to these special categories can waive the right voluntarily and unequivocally. They shall not be informed by a lawyer but by a judge or police officer of the consequences of waiving the right and of the possibility that the decision to waiver this right can be revoked. According to the Directive, a waiver of this right can only be given after the suspect or accused person is informed, orally or in writing, about the content of this right and the possible consequences of waiving it. Next to that, the waiver shall be given voluntarily and unequivocally. The requirements of the Directive as far as waivers are concerned appear to have been fulfilled in this second draft. In the first draft bill, informing the suspect of the consequences thereof was limited to serious offences. ${ }^{105}$ Noting the circumstances under which the waiver was given, the other requirement of the Directive is supposed to be already regulated. Next to that, the proposed Article 28a, second paragraph of the CPC, instructs the officer to report on the providing of information. However, it remains to be seen whether or not the existing set of rules is sufficient. The Dutch Code of Criminal Procedure has a general provision article, Article 152 of

102. Ibid., at 73 .

103. A serious offence in the first draft was defined as an offence, punishable with a sentence of six years imprisonment.

104. Other requirements of Art. 4 of the Directive are met by, amongst other articles, Art. 218 CPC.

105. Ibid., at 104 the CPC, obligating investigative clerks to note all of their actions in writing. Whether or not the general provision together with the provision instructing to provide information suffices to meet the requirement set out by the Directive remains to be seen; no specific rules about the registration of circumstances under which the accused waivered its rights, as demanded by Article 9 of the Directive, are laid down in the Dutch draft bill. Until now, this general provision did not contribute to the fact that records of interrogation contained a literal reflection of questions asked during interrogation of a suspect or accused person. ${ }^{106}$ Rule and practice will be decisive for adequate implementation of the Directive.

\subsection{Articles 5, 6, and 7 of the Directive}

Articles 5, 6, and 7 will not be discussed in this paper except for the fact that the Directive requires the Member State to ensure that a suspect or accused person deprived of his liberty, has the right to inform at least one person of his deprivation of liberty without undue delay if he wishes to do so. This paper, as stated before, does not focus on this right; however, it should be noted that when children are involved as a suspect or accused person, the holder of parental responsibility is informed of the deprivation of liberty and of the reasons thereto, unless contrary to the interests of the child. This requirement appears to be answered by Article 488b of the Criminal Procedure Code ordering the assistant public prosecutor to inform the parents or custodian of the arrest of the minor as well as the Council for Child Protection.

Articles 8 and 9 of the Directive, as mentioned earlier, regard derogations and waivers. As a general rule, temporary derogations can be made if they are proportionate and do not go beyond what is necessary. Next to that, they need to be strictly limited in time and not solely based on the type or seriousness of the alleged offence. Beyond these requirements, certain temporary derogations have to be authorised by judicial authorities, duly reasoned and open for submission to judicial review. Other derogations need to be authorised by a competent authority and open for submission to judicial review. The Dutch draft bill contains a number of possibilities to derogate the rights of the suspects or accused persons.

\section{The Supreme Court Verdict of 1 April $2014^{107}$}

Before drawing conclusions, it needs to be pointed out that the Supreme Court made a judgement on 1 April 2014, in other words, after the adoption of the
106. When the suspect or accused person uses his rights to remain silent, officials' records of the interrogation quite often are limited to the mentioning of the duration of the interrogation, participants, and breaks and the fact that the suspect or accused person remained silent. Questions that remained unanswered are not reported.

107. ECLI:NL:HR:2014:770. 
Directive, on the presence of a lawyer during police interrogation. The defence complained about the use of the statement of the suspect. This statement was made without having consulted his lawyer prior to the interrogation. He was however made aware of his right to remain silent. The Supreme Court ruled that the defence complaint on the use of the statement obtained in violation of the Salduz rights had to be made in an earlier stage of the legal proceedings and cannot be made at first at the Supreme Court.

More interesting however is the ruling on the question of the presence of a lawyer during interrogation. In his conclusion the Attorney-General questions if not having a lawyer present during the interrogation can still be considered as justified with regard to the Navone case ${ }^{108}$ as well as the Directive. ${ }^{109} \mathrm{He}$ concludes that this question has to be answered in a negative way. ${ }^{110}$ The Supreme Court however rules different. They argue that the Directive has to be implemented in national legislation on 27 November $2016^{111}$ which implicates that no rights can be derived from the Directive until that date. Next, they argue that the fact alone that a time limit has been set for the Directive implies that legislation of a Member State does not have to comply with the requirements, set out in the Directive, as is currently applicable for the Netherlands. ${ }^{112}$ Then, the Supreme Court ascertains that no legislation founded on the Directive exists and stated that, bearing the political and policy considerations as well as the organisational and financial aspects in mind, creating a general regulation regarding legal assistance during police interrogation would exceed its judicial function. The fact that the ECtHR in some cases ruled that the lack of legal assistance meant a breach of Article 6 of the ECHR did not change the approach to the judicial function of the Supreme Court. According to the Supreme Court, the cases of the ECtHR do not support the general conclusions regarding the reach of the right to legal assistance not to consequences of a breach thereof. ${ }^{113}$ The Supreme Court however encourages the legislator to have a dynamic approach to regulating this matter. This encouragement is underlined by the remark that if legal regulation does not come about, the rulings on the reach and content of the right to legal assistance might be different. ${ }^{114}$

It appears that the approach of the Supreme Court is a political one. This can be deducted from the fact that the Supreme Court points out that their judicial function is too narrow to rule otherwise. Legally the approach of the Directive not having entered into force is correct. The same goes for the legal approach that the

108. Ibid., at 15

109. In the Netherlands prior to a ruling, the Attorney-General at the Supreme Court present his findings on the case in a so-called conclusion.

110. ECLI:NL:PHR:2013:1424.

111. Ibid., at 16

112. ECLI:NL:HR:2014:770, para. 2.5.2

113. ECLI:NL:HR:2014:770, para. 2.5.3.

114. ECLI:NL:HR:2014:770, para. 2.5.4. judgements of the ECtHR are too much bound by the specific circumstances of the cases involved. With this ruling, the Dutch Supreme Court places the ball in the court of the Ministry of Security and Justice where it has been since the Salduz judgement. This is emphasised by the encouragement to regulate this legally.

The Supreme Court has a justified argument to do so. The Dutch State has shown a rather restrained approach on implementing the Salduz judgement. It has been short of six years since the ECtHR has judged in the Salduz case, and in the meanwhile a Directive of the European Union has been adopted. The Dutch State however has not managed to implement legislation until now. Legislation is still in the phase of a draft proposal.

\section{Conclusion}

In response to the rulings of the ECtHR in, amongst others, but primarily, the case of Salduz v. Turkey, the Dutch government saw an obligation to initiate a change in Dutch criminal procedure on the traditionally rather 'lean' point of legal assistance and police interrogation. It initiated legislation which resulted in a first draft bill 'Legal assistance and police interrogation' composed by the Dutch Ministry of Security and Justice. The proposed articles in the draft bill were rather lean in fulfilling all the requirements resulting from the right to a fair trial laid down in Article 6 of the ECHR. The margin of appreciation was interpreted as rather wide by the drafters of the draft bill and the question already arose as to whether or not the criteria set out by the ECtHR would be met by the draft bill. In May of 2013 the European Union proposed a Directive containing minimum rules relating to the right to access to a lawyer and to communicate with him, which was adopted in November of that same year. This Directive, unlike the verdicts of the ECtHR, leaves a more narrow margin of appreciation to the Member States since the rules are not to be deducted from verdicts explaining the right to a fair trial but are explicitly laid down in the provisions. Following the Directive, the first draft was withdrawn and two separate draft bills were proposed. One focussed on implementing the elements necessary to comply with the Directive, the other with a focus on changing the regulations on the first phase of the criminal investigation. The aim of this paper was to study whether or not the draft bill, with a focus on implementing elements necessary to comply with the standards of that Directive, actually achieves that goal. The Directive sets out a number of minimum rules which Member States have to apply in the national legislation. One of those minimum rules is the right of access to a lawyer at the police interrogation. This minimum right is answered by the second Dutch draft bill in allowing the suspects or accused persons to discuss his position and be provided with information during a time period of half an hour. During the interrogation itself, the lawyer is allowed to be present. This appears to 
meet the requirements made by the Directive although the limitation in the draft bill to converse with a lawyer still represents the Dutch point of view on interrogation. The interest of a good ordered and regulated interrogation appears to prevail and could probably be conflicting with the point of view of the ECtHR in explaining Article 6 of the ECHR. We must fear that the reluctant tradition under Dutch law will not support an open and effective interpretation nor create an extensive practice.

It is understandable that the drafters of the Dutch draft bill kept the process of the interrogation as central point of view in the proposal because it has since long time been the tradition in the Netherlands to have a strong reliance on the professionalism and integrity of the Dutch police. It appears that the drafters took the rulings of the Strasbourg Court, explaining Article 6 of the ECHR, as far as legal assistance is concerned too lightly. The Supreme Court made a political choice by not immediately condemning the current approach of interrogation by stating that the Directive is, as such, not yet legally binding and judgement of the ECtHR are too much based on specific cases. Progress however is required. A new draft already had to be made. The current draft fortunately leaves less space for interpretation. It remains to be seen whether or not this new draft will enter into force without amendments. Time is running out however: the countdown for the change in Dutch law and - traditionally rather different - practice has started and ends on 27 November 2016. And even if the law is accepted, the ECtHR will control the application in concrete cases on the basis of Article 6 as 'living instrument'! The topic is to be continued in the coming years! 